\title{
Impact of mechanical Arenicola dredging on the benthic fauna communities: assessed by a morphological and molecular approach
}

\author{
Lise Klunder ${ }^{1, *}$, Judith D. L. van Bleijswijk ${ }^{2}$, Loran Kleine Schaars ${ }^{1}$, \\ Henk W. van der Veer $^{1}$, Pieternella C. Luttikhuizen ${ }^{1}$ \\ ${ }^{1}$ Department of Coastal Systems, Royal Netherlands Institute for Sea Research, PO Box 59, 1790 AB Den Burg Texel, \\ The Netherlands \\ ${ }^{2}$ Department of Marine Microbiology and Biogeochemistry, Royal Netherlands Institute for Sea Research, PO Box 59, \\ 1790 AB Den Burg Texel, The Netherlands
}

\begin{abstract}
Lugworm Arenicola spp. dredging affects the intertidal benthic community in the Dutch Wadden Sea. Previous studies have found contradicting results regarding the recovery rates of targeted and non-targeted macrozoobenthic species, and meiobenthic communities have been neglected in these studies. The current study explores the short-term effects of dredging on both the macrofaunal and the meiofaunal communities using both a morphological and molecular approach. Benthic samples were collected right before and regularly after dredging for up to $1.5 \mathrm{yr}$ at both control and fished transects. Significant differences between the control and fished transects were found by morphological and molecular approaches. Ordination analysis suggests distinct community compositions between control and fished transects in the first months after dredging. Opportunistic species with short life cycles, typically more than 1 generation $\mathrm{yr}^{-1}$, thrived more in the fished transects during the spring/summer season compared to these species in the control transects in the same season, whereas recovery for long-lived species was slow. Both approaches showed similar results; however, compared to the morphological approach, the molecular approach was more sensitive to the effects due to a larger set of benthic taxa.
\end{abstract}

KEY WORDS: Anthropogenic effects · Metabarcoding $\cdot$ Intertidal $\cdot$ Lugworm dredging $\cdot 18 \mathrm{~S}$ rDNA

\section{INTRODUCTION}

Intertidal soft-sediment systems provide wideranging ecosystem services (Levin et al. 2001). Stretching across Dutch, German and Danish coastlines, the Wadden Sea represents both the largest and one of the last remaining relatively undisturbed intertidal areas in the world and appears on UNESCO's list of world heritage sites. The Wadden Sea is a shallow coastal region with large tidal flats consisting of productive soft sediment. The ecosystem is mainly driven by benthic primary and secondary production (Wolff \& Binsbergen 1985, Compton

\footnotetext{
*Corresponding author: lise.klunder@nioz.nl
}

et al. 2013, Christianen et al. 2017). On these mudflats, the lugworms Arenicola marina and, in smaller numbers, A. defodiens, are widespread and dominant burrowing polychaetes that engineer the sediments (Luttikhuizen \& Dekker 2010). Adult specimens grow up to $10-20 \mathrm{~cm}$ in length and can live up to 6 yr (Bijkerk \& Dekker 1991). The lugworms live in a $20-40 \mathrm{~cm}$ deep U-shaped burrow with a funnelshaped shaft through which surface sediment slides down. Sediment particles are ingested and are then defecated at the surface. This ecosystem engineer is a known key species for the benthic mudflat community, as it is a major source of bioturbation and bio-

() The authors 2021. Open Access under Creative Commons by Attribution Licence. Use, distribution and reproduction are unrestricted. Authors and original publication must be credited. 
irrigation on the intertidal mudflats of the Wadden Sea (Volkenborn et al. 2007).

Arenicola spp. are harvested by hand or mechanically in some areas as bait for sport fishing. Mechanical dredging involves digging gullies $(0.4 \mathrm{~m}$ deep, $1 \mathrm{~m}$ wide, 200-500 m long) at high tide. Dredged sediment is mixed with water and sieved to harvest the larger organisms; the smaller organisms are discarded in and around the gullies (van den Heiligenberg 1987, Beukema 1995, Leopold \& Bos 2009). This mechanical lugworm dredging impacts benthic communities, including lugworms as well as non-target species. Lugworm biomass and abundance are lower at dredging sites shortly after mechanical harvesting (van den Heiligenberg 1987). Different post-harvest recovery rates for the lugworm Arenicola spp. as well as for other macrozoobenthic species have been observed (McLusky et al. 1983, van den Heiligenberg 1987, Beukema 1995). Effects of dredging on the benthic communities could either result from the relocation and disturbance of sediment and smaller species or from the complete removal of lugworms in the dredged area. As the lugworm affects its surroundings by bioturbation of the sediment, the effects of completely removing this species extend beyond its absence and can be complicated. Volkenborn \& Reise (2006) demonstrated a positive effect on the biomass of several benthic species shortly after their removal. However, in the long-term, lugworm presence was proven to be essential for a sustainable community (Volkenborn \& Reise 2006, Volkenborn et al. 2007).

Research into the effects of lugworm dredging in the Wadden Sea have so far focused solely on macrozoobenthic species and have yielded contradicting results. Drent (2013) reported no differences in macrozoobenthos between dredged areas and reference areas at the Vlakte van Kerken, but at the Balgzand area in the same tidal basin, Beukema (1995) found that the biomass in dredged areas only recovered after several years. However, macrozoobenthos might not be the most appropriate indicator for the effects of dredging on the benthic community. Meiofauna species are key species in the marine food web and are known to be good indicators of ecosystem health (Balsamo et al. 2012, Zeppilli et al. 2015). With new metabarcoding techniques, it is now feasible to expand the scope of such research on the impact of lugworm dredging to also more easily incorporate meiofauna. Including this part of the community might provide better insight into the recovery rates of the local benthic community as a whole and the processes that occur during recovery.
This study explored the short-term effects of mechanical lugworm dredging on benthic meiofaunal and macrofaunal communities. Benthic and sediment samples for grain size analysis were taken before and after digging in fished and control (nonimpacted) sites. Species composition of the prefishing and post-fishing samples was analysed by both morphological taxonomy and by using a molecular (metabarcoding) approach. The aims of the study were to (1) examine whether mechanical Arenicola spp. dredging impacts the composition of benthic communities; (2) explore recovery rates of lugworm abundances and non-targeted fauna following dredging and (3) compare morphological and molecular approaches in their abilities to detect biological change and recovery following an anthropogenic disturbance.

\section{MATERIALS AND METHODS}

\subsection{Field sampling}

An experimental plot was created on tidal flats in the western part of the Dutch Wadden Sea, Vlakte van Kerken, north-east of the isle of Texel. The plot comprised 18 sampling stations, divided over 3 control transects and 3 experimental transects (Fig. 1). All stations were sampled once before the experimental transects were fished by the company Arenicola B.V. (T0) and another 16 times (T1-T16) after the disturbance across a temporal range of $1.5 \mathrm{yr}$ (Table 1). During each sampling event, all transects were photographed, and 3 cores were taken at each station: one larger core (177 $\mathrm{m}^{2}$ surface area, 25-30 cm depth) for traditional morphological identification of macrofauna and 2 smaller cores $\left(5.60 \mathrm{~cm}^{2}\right.$ area, $10 \mathrm{~cm}$ depth) for the molecular identification and grain size analysis, respectively. All cores were taken simultaneously. We chose the current method of 3 separate cores rather than splitting them, as it applies fewer treatments to the sample which might introduce contamination (Aylagas et al. 2016, Elbrecht et al. 2017). Grain size analysis was performed following Compton et al. (2013) and Klunder et al. (2019a).

\subsection{Morphological identification}

The macrofaunal communities of the intertidal Wadden Sea have been studied for decades within our research group at NIOZ. Sampling strategies and morphological identification within this research 


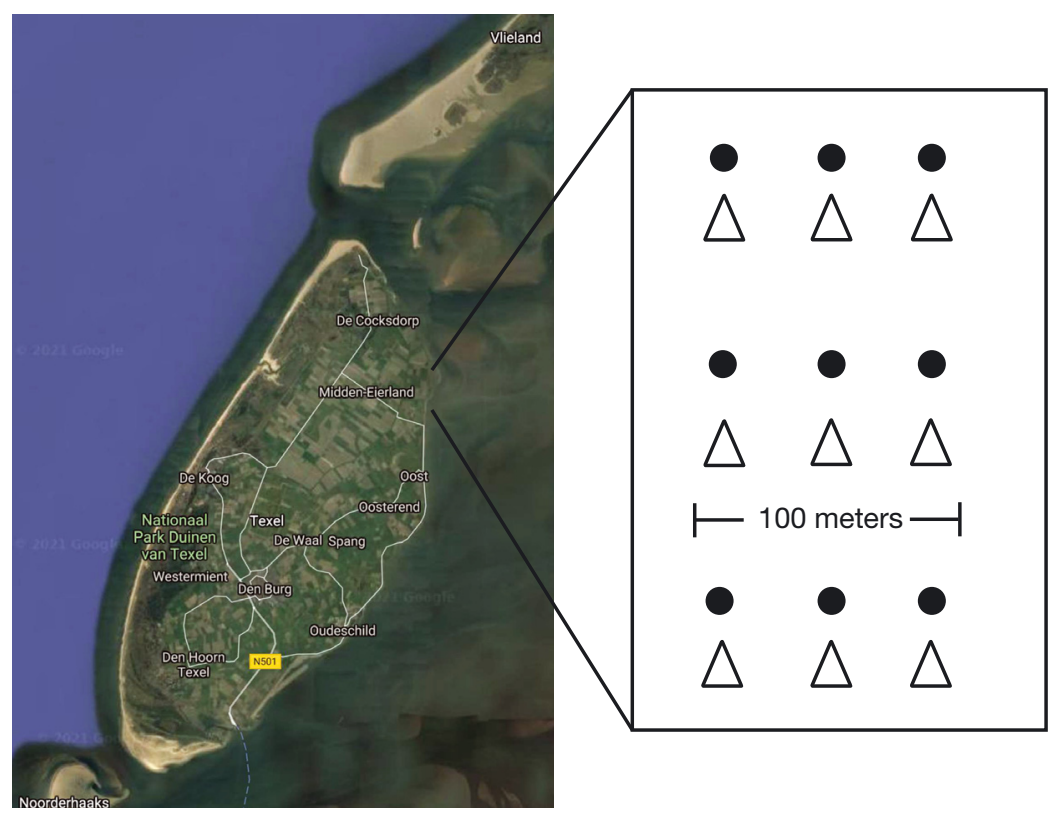

Fig. 1. Map of Texel and a graphical description of the sampling transects. Round sampling points represent the control transects, triangles represent the fished transects

Table 1. Sampling codes and their corresponding sampling date. Arenicola fishing was executed between T00 and T01

\begin{tabular}{|cc|}
\hline T code & $\begin{array}{c}\text { Date } \\
\text { (dd-month-yyy) }\end{array}$ \\
\hline T00 & 20-mar-2016 \\
T01 & 21-mar-2016 \\
T02 & 31-mar-2016 \\
T03 & 05-apr-2016 \\
T04 & 11 -apr-2016 \\
T05 & 20 -apr-2016 \\
T06 & 09 -may-2016 \\
T07 & 23 -may-2016 \\
T08 & 06 -jun-2016 \\
T09 & 04 -jul-2016 \\
T10 & 31 -aug-2016 \\
T11 & 14 -nov-2016 \\
T12 & 13 -mar-2017 \\
T13 & 09 -may-2017 \\
T14 & 23 -may-2017 \\
T15 & 06 -jun-2017 \\
T16 & 26 -jun-2017 \\
\hline
\end{tabular}

builds on the knowledge obtained throughout these years (Beukema 1974, Beukema \& Cadée 1997, Beukema \& Dekker 2012, Compton et al. 2013).

Samples for morphological identification were washed in the field over a $1 \mathrm{~mm}$ mesh sieve. Sieve residues were stored in a jar in a cool and dark place and were processed within $36 \mathrm{~h}$ after sampling. Spe- cies retained in sieve were sorted by hand and identified while alive by experienced taxonomists based on morphological characteristics according to Hartmann-Schröder (1996) and Hayward \& Ryland (1995). Molluscs, crustaceans and polychaetes were identified to the genus level, whereas Oligochaeta were identified to the phylum level.

\subsection{Molecular identification}

Prior to DNA extraction, extracellular DNA was removed from the samples by rinsing with a saturated phosphate buffer $\left(\mathrm{Na}_{2} \mathrm{HPO}_{4} ; 0.12 \mathrm{M}\right.$, pH $\left.\approx 8\right)$. Subsequently, the samples were cryodesiccated and ground in liquid nitrogen. DNA was extracted from $10 \mathrm{~g}$ of the homogenized sediments using the Powermax Soil ${ }^{\mathrm{TM}}$ DNA isolation kit (Qiagen). The universal F04 and R22 primer pair for the metazoan community (Sinniger et al. 2016) was used to amplify a $450 \mathrm{bp}$ part of the $18 \mathrm{~S}$ gene, and both the forward and reverse primers were extended with $12 \mathrm{nt}$ unique barcodes for sample identification in the bioinformatics process. PCR amplifications were performed in triplicate in a $50 \mu \mathrm{l}$ reaction, containing

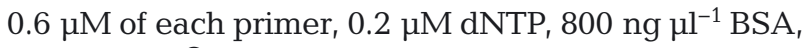
1 U Phusion ${ }^{\circledR}$ High-Fidelity DNA Polymerase (Thermo Scientific), $1 \times$ Phusion ${ }^{\circledR}$ HF Buffer (Thermo Scientific) and $5 \mu \mathrm{l}$ of DNA extract. The thermal cycle started with an initial cycle of $30 \mathrm{~s}$ at $98^{\circ} \mathrm{C}$, followed by 27 cycles, each comprising $10 \mathrm{~s}$ at $98^{\circ} \mathrm{C}, 20 \mathrm{~s}$ at $60^{\circ} \mathrm{C}$ and $30 \mathrm{~s}$ at $72^{\circ} \mathrm{C}$, followed by a single elongation step at $72^{\circ} \mathrm{C}$ for $5 \mathrm{~min}$. The PCR products were purified by both excising $450 \mathrm{bp}$ bands from a 1\% agarose gel and the Qiaquick Gel Extraction Kit (Qiagen). The final samples were quantified with a Qubit ${ }^{\mathrm{TM}} 3.0$ fluorometer (Qiagen) and pooled in equimolar quantities together with blank PCR controls. Amplicons were submitted for sequencing at Useq (Utrecht) on an Illumina MiSeq using the $2 \times 300$ bp V3 kit.

\subsection{Bioinformatics}

Raw sequences were quality filtered $(\leq 30$ score over $75 \%$ of the positions), de-replicated and clustered at a $98 \%$ similarity cut-off. Singleton clusters were discarded and the remaining operational taxo- 
nomic unit (OTU) clusters were taxonomically assigned using the RDP Classifier against the SILVA 18S rRNA database (release 128; Pruesse et al. 2007) and our local reference database (Genbank accession numbers MZ709983-MZ710042). Taxonomic assignment was performed at a 0.8 and 0.5 minimum confidence threshold. OTUs identified as macrofauna taxa were extracted from the 0.8 data set; the rest were extracted from the 0.5 data set. Taxonomicassigned OTUs were clustered at the genus level if possible. If no genus-level assignment was possible, higher level assignments were used. Raw Illumina sequences were deposited in the European Nucleotide Archive (ENA accession number: PRJEB46793).

\subsection{Data analysis}

The mud content was relatively stable between 0.8 and $1.2 \%$; therefore, percentage silt was used as a further measure for grain size analysis. Silt content was compared between fished and control sites using ANOVA, including the fished and control transect pairs as a random effect.

For the morphological approach, the abundance (counts) of each genus per sample was assessed. Large variations were observed in the count data of both Oligochaeta and Urothoe sp. Variations were related to observer and sampling bias, respectively and were removed from the community analysis. For the molecular approach, the relative read abundance (RRA) data per OTU was used as a measure of abundance. This transformation was chosen over rarefaction as it preserves valid read abundance data (McMurdie \& Holmes 2014, Lanzén et al. 2016). Also, the RRA approach was chosen over a frequency of occurrence approach (FOO), as the sampled environment was very homogeneous, resulting in over $90 \%$ presence for many abundant species. This homogeneity would hinder the FOO approach in detecting differences between fished and control sites (Deagle et al. 2019). Both the count data for the morphological approach and the RRA were Hellinger-transformed (Legendre \& Gallagher 2001), and dissimilarity distances were calculated using the Bray-Curtis equation. Benthic community composition was explored using multi-dimensional scaling (MDS) ordinations based on the dissimilarity distances. Subsequently, permutational multivariate analysis of variance (PERMANOVA) was employed to determine the effect of fishing on the benthic community, and a SIMPER analysis was implemented to determine which taxa were responsible for this effect.

All calculations, statistical analyses and data visualisations were performed in $\mathrm{R}$ version 3.5.2 (R Core Team 2018).

\section{RESULTS}

\subsection{Field observations}

A selection of the photos taken of each transect during the sampling events is shown in Fig. 2. A dredged gully was visible in the experimental transects immediately after mechanical dredging (T01). The gullies filled quickly and were covered by a layer of diatoms in the first 2 mo (spring season) (T04 and T06). The gullies remained visible as wet transects within the mudflats throughout the summer season (T08). Although only vaguely visible in the photograph, the layer of diatoms appeared again the year after, in the spring season (T13). Unfortunately, porosity of the sediment was not measured, but our observations described below are consistent with a difference in porosity between fished and control transects. All control transects consisted of solid sed-
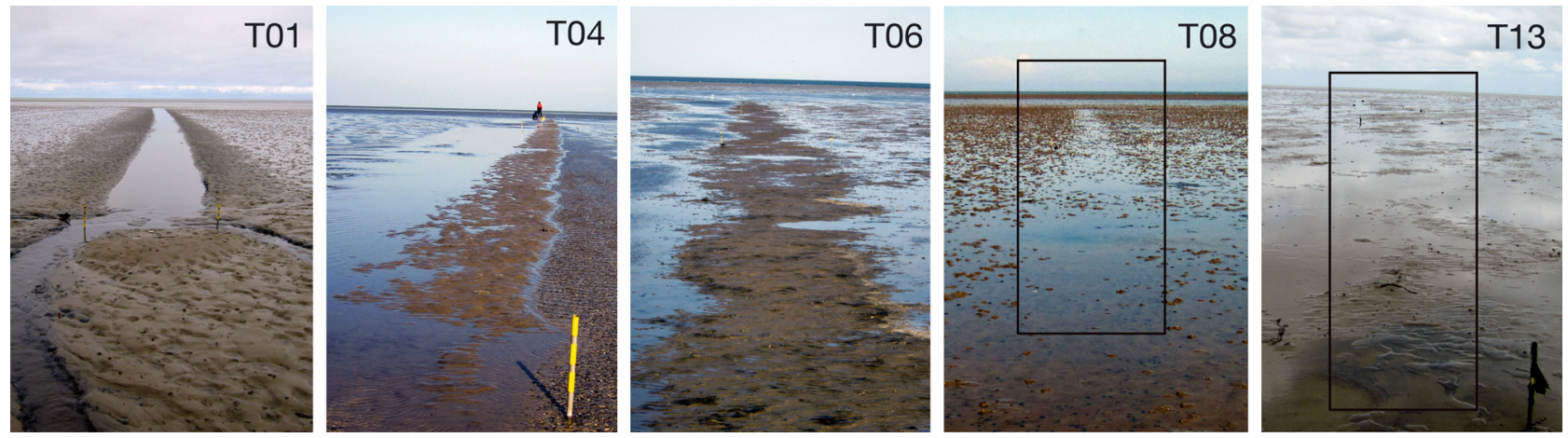

Fig. 2. Photographs of the most southern fished transect taken at T01, T04, T06, T08 and T13, respectively 
iment, whereas anecdotally, the sediment in the fished transects felt looser during sampling from T1-T13. No differences were observed after T13. It was not possible to stand on the fished transects for the entire first year of the study. The average percentage of silt for all samples within either the controlled or fished transects for each sampling event are shown in Fig. 3. Silt content was statistically correlated with treatment when time was considered in the formula (ANOVA, $F_{1,16}=2.02, \mathrm{p}=0.01$ ).

\subsection{Community analysis}

Benthic community composition was explored using MDS ordinations based on the count data per taxon from the morphological approach and the RRA for OTUs from the molecular approach (Figs. 4, S1 \& S2 in the Supplement at www.int-res.com/articles/ suppl/m673p017_supp.pdf). The ordinations from both approaches at T00 indicate no difference in composition between the control and fished transects

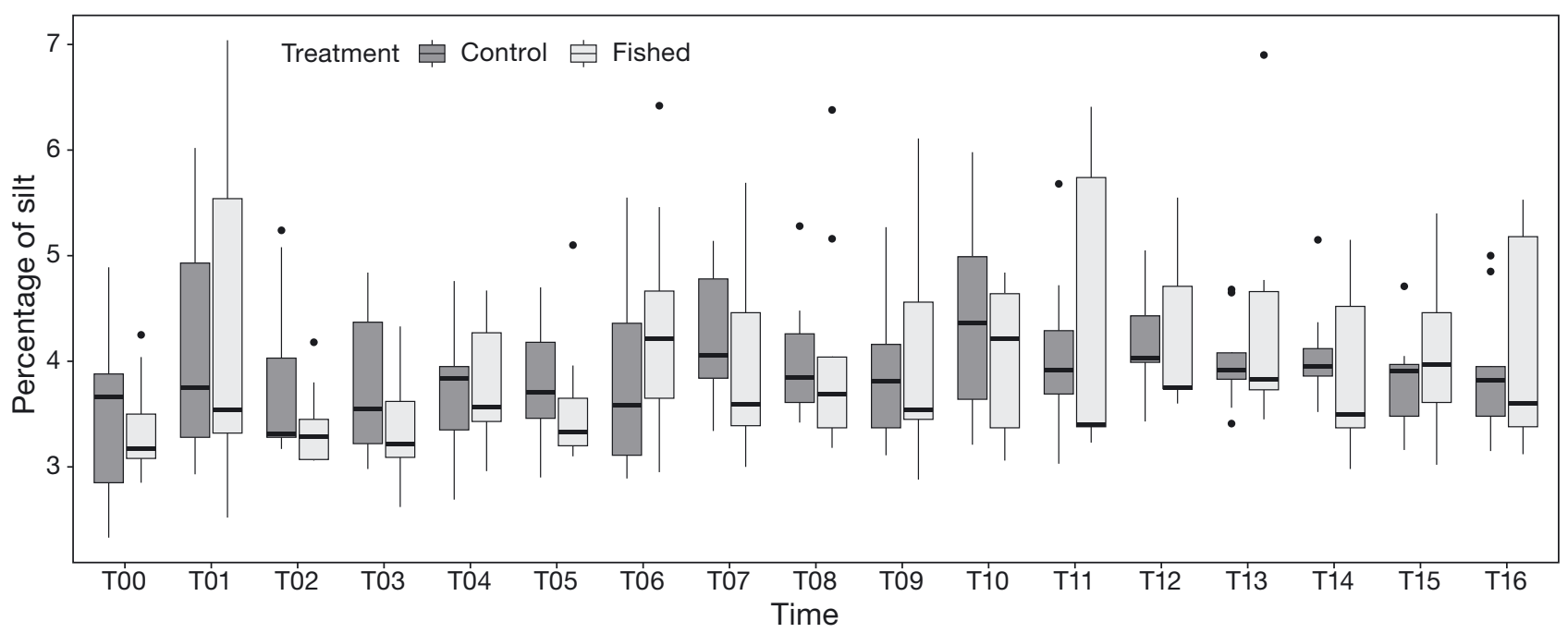

Fig. 3. Sediment composition comparison between control and fished transects. Boxplots show percentage of silt for all sampling points within 1 experimental setup. Shown in the boxplot are the median, lower and upper quartile in the boxes, and the dots represent outliers
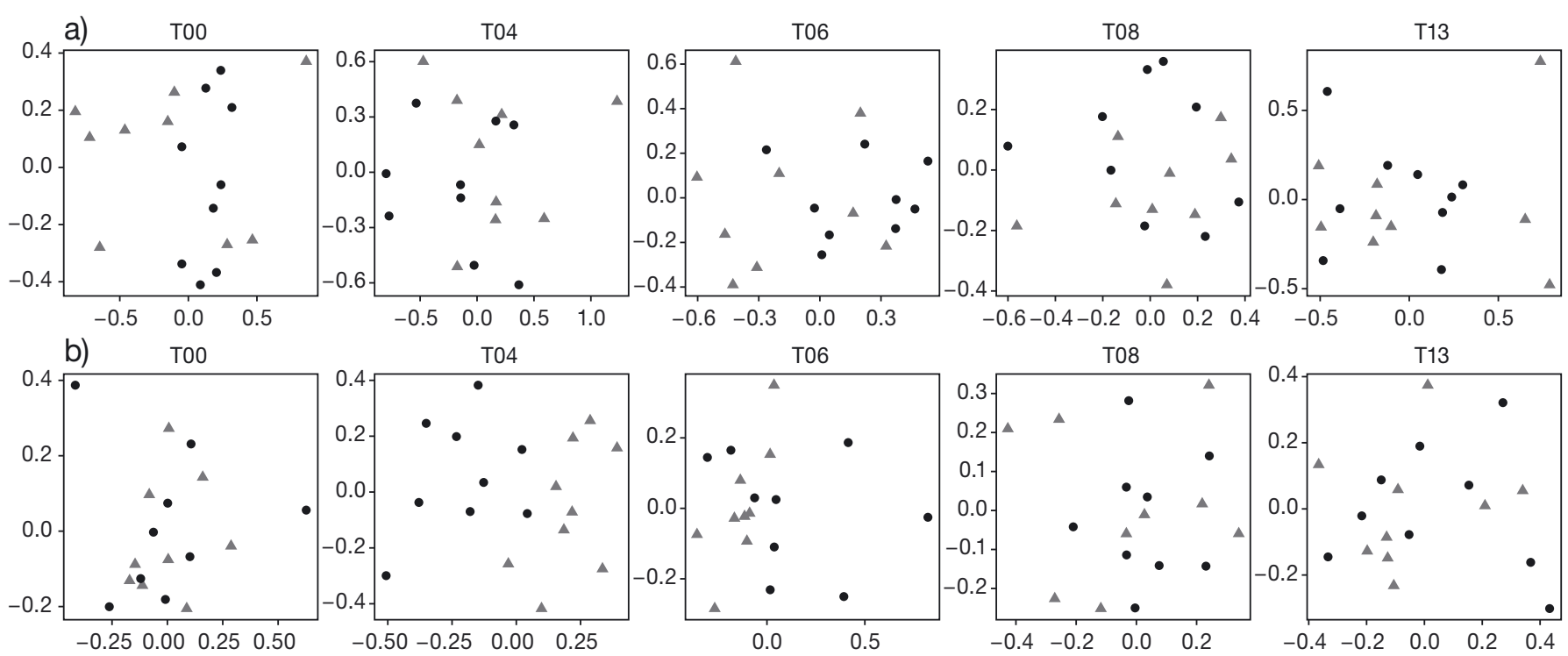

Fig. 4. Selection of multi-dimensional scaling (MDS) ordinations based on the benthic community composition for the (a) morphological approach and (b) molecular approach. Circles: control transects; triangles: fished transects. MDS ordinations for all sampling events are shown in Figs. S1 \& S2 
Table 2. Morphological and molecular analysis of benthic diversity. Results of permutational multivariate analysis of variance (PERMANOVA) analysis on multi-dimensional scalingordinations for each sampling event. PERMANOVA analysis tested for a difference in community composition between control and fished transects. Significant effects $(p \leq 0.05)$ are shown in bold

\begin{tabular}{|cccccc|}
\hline \multirow{2}{*}{ Time } & \multicolumn{3}{c}{ Morphological- } & \multicolumn{2}{c|}{ Molecular -} \\
& $F$ & $\mathrm{p}$ & $F$ & $\mathrm{p}$ \\
\hline T00 & 2.1373 & 0.088 & 0.8460 & 0.886 \\
T01 & 2.2356 & $\mathbf{0 . 0 3 8}$ & 2.1582 & $\mathbf{0 . 0 0 3}$ \\
T02 & 1.2021 & 0.315 & 2.1408 & $\mathbf{0 . 0 0 7}$ \\
T03 & 1.7589 & 0.099 & 1.6812 & $\mathbf{0 . 0 0 5}$ \\
T04 & 1.8543 & 0.090 & 2.4205 & $\mathbf{0 . 0 0 1}$ \\
T05 & 2.1988 & $\mathbf{0 . 0 3 5}$ & 1.4550 & $\mathbf{0 . 0 4 6}$ \\
T06 & 2.4038 & $\mathbf{0 . 0 4 6}$ & 1.4748 & $\mathbf{0 . 0 0 3}$ \\
T07 & 2.3629 & $\mathbf{0 . 0 4 7}$ & 0.9647 & 0.502 \\
T08 & 1.2927 & 0.245 & 1.0453 & 0.323 \\
T09 & 0.7163 & 0.656 & 1.0732 & 0.254 \\
T10 & 0.7189 & 0.621 & 0.8401 & 0.844 \\
T11 & 0.4503 & 0.719 & 0.7161 & 0.965 \\
T12 & 0.4907 & 0.776 & 1.1266 & 0.209 \\
T13 & 0.4428 & 0.837 & 0.9007 & 0.662 \\
T14 & 0.9427 & 0.431 & 0.9241 & 0.604 \\
T15 & 0.8886 & 0.550 & 0.9732 & 0.465 \\
T16 & 1.4913 & 0.168 & 0.9941 & 0.404 \\
\end{tabular}

when assessed by PERMANOVA (Table 2). Significant differences in composition were found at T01, T05, T06 and T07 using the morphological approach and from T01-T06 using the molecular approach.

SIMPER analysis for the samples in the morphological approach suggested that the primary drivers for the difference at T01 were a higher abundance of Scoloplos sp. in the fished transects and a lower abundance of Tharyx sp. Later, at T05, T06 and T07, a higher abundance of Capitella sp. and Pygospio sp. in the fished transects was observed. For the molecular approach, Simper analysis suggested that differences in community species composition were mainly due to meiofaunal taxa. At T01, higher RRA of the meiofauna arthropod taxa Podocopida and Harpacticidae was observed. For T02-T06, lower RRA for several nematode taxa within the fished transects was the main driver of the differences in community composition.

\subsection{Taxonomic composition}

Annelida taxa were the predominant taxa recovered by the morphological approach, while arthropods (mostly Urothoe sp. and Crangon sp.) and molluscs (mostly Limecola sp.) were detected less frequently (Table S1). The abundance of adult specimens of Arenicola, the targeted species within the experimental fished transects, was significantly lower in the fished transect (Wilcoxon, $W=10$, p < 0.005) (Figs. $5 \&$ S3). Although the abundance of Arenicola sp. was already lower pre-fishing at T00, this difference in abundance doubled between T03 and T07. On the contrary, the abundance of juvenile Arenicola was higher in the dredged transects than in the control transects at all post-fishing sampling times in the first year (Wilcoxon, $W=7.5, \mathrm{p}<0.005$ ), whereas their abundance was higher in the control transects compared to the fished transects predredging. This effect was still present in the second year (T14, T16) (Fig. S3). Other smaller taxa, such as Capitella sp. and Pygospio sp., were observed in increased abundances within the fished transects (Wilcoxon, respectively, $W=16.5, \mathrm{p}<0.05$ and $Z=$ 15, p $<0.05$; Fig. S4). Both taxa varied most markedly in their abundance between May and July in both the first and second years (respectively T6-T9 and T13-T16).

With the molecular approach, OTUs assigned to the phyla Nematoda, Arthropoda and Annelida contributed the most total number of reads (Figs. 6 \& S5-S7). Overall RRA within Phylum Nematoda was lower for fished transects compared to control transects (Wilcoxon, $W=25, \mathrm{p}<0.05$ ). However, none of the taxonomic orders separately showed a significant decline. In the first 2 mo after fishing, Chromadorida and Monhysterida had a lower RRA (T2-T5). RRAs of Araeolaimida were lower later in the summer in dredged transects compared to control transects (T5-T7). By contrast, RRA of all arthropod taxa, especially Podocopida, was higher in dredged transects (Wilcoxon, respectively, $W=21, \mathrm{p}<0.05$ and $W=0$, $\mathrm{p}<0.0005)$. Likewise, RRA of Annelida was highest in the fished transects (Wilcoxon, $W=23, \mathrm{p}<0.05$ ). Again, none of the taxa separately showed a significant difference; however, the RRA of Orbiniidae (Scoloplos sp.) and Polynoidae were higher in the first 2 mo in dredged transects compared to control transects.

\subsection{Morphological versus molecular approach}

The molecular approach recovered a larger number of OTUs than the morphological approach, respectively 98 versus 40 . A large proportion of the extra OTUs detected were meiofaunal taxa (i.e. Nematoda, Platyhelminthes and small Arthropoda). However, from these 98 OTUs, 51 taxa were taxonomically assigned as macrofauna by the molecular approach, 11 more than detected with the morpho- 


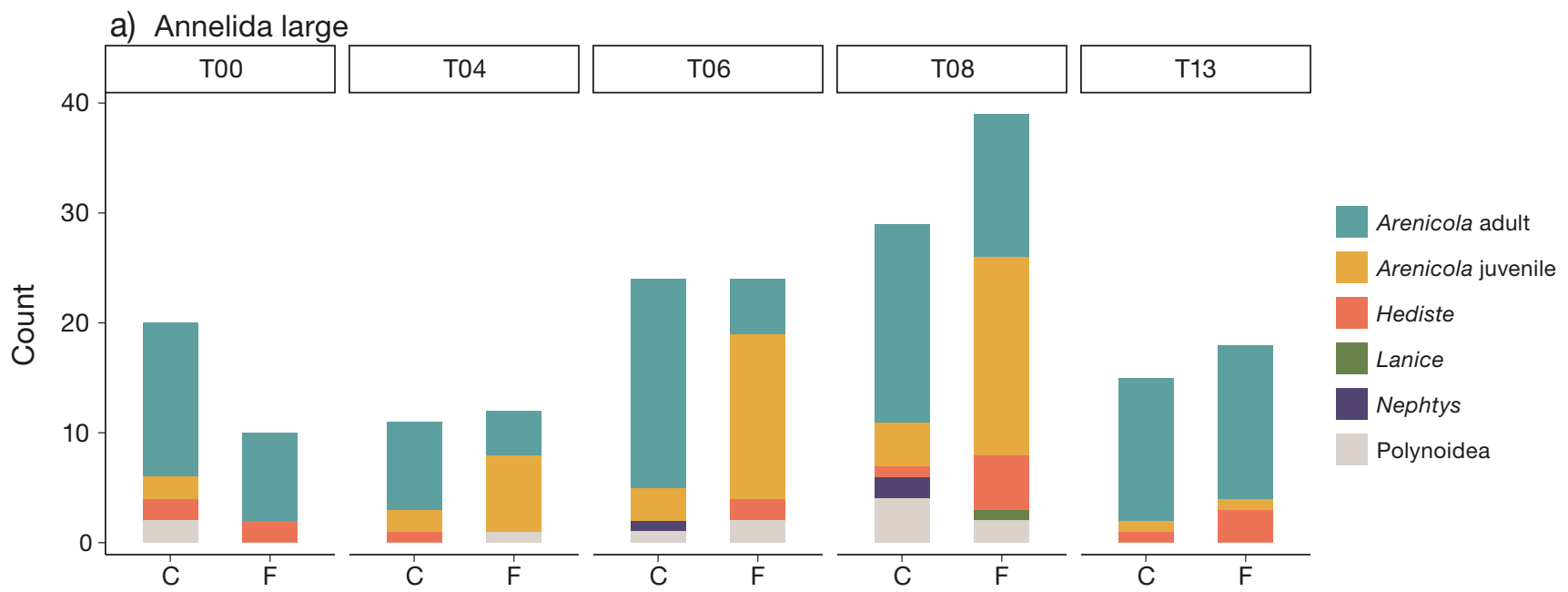

b) Annelida small

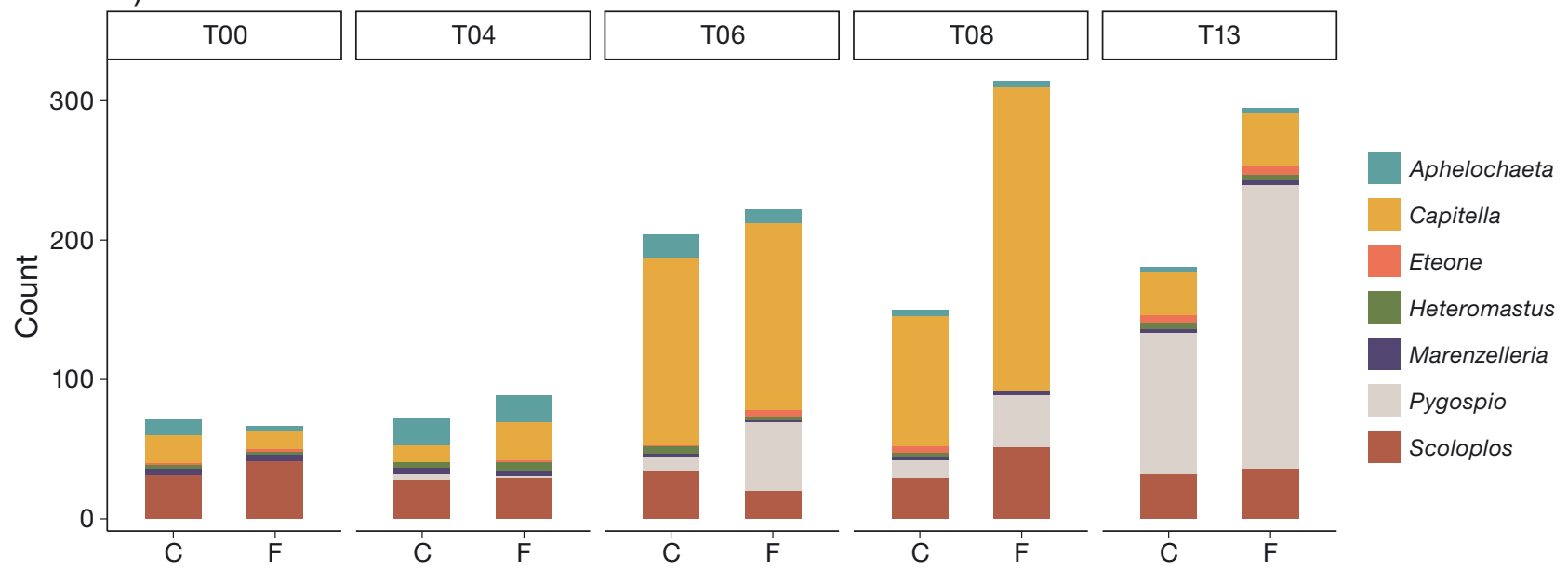

Fig. 5. Morphological analysis of benthic biodiversity: selection of barplots based on abundance data for (a) larger and (b) small Annelida genera or families. Barplots for all sampling events can be found in Figs. S3 \& S4. C: control; F: fished; TXX: sampling time point

logical approach. Benthic macrofauna taxa which were not detected with the morphological approach included Lagis sp. and Magallana sp. Both approaches demonstrated comparable patterns with respect to the effects of Arenicola spp. dredging. For instance, the higher abundance of Annelida in dredged transects compared to control transects in the first spring season (T6-T8) was comparable between the 2 methods. However, the outcomes of the morphological and molecular approaches were not comparable with respect to time and seasonality. The RRA for Annelida within the spring season was lower than at the sampling times before, whereas the total abundance in the morphological approach was higher than at the earlier sampling times.

\section{DISCUSSION}

The present study applied both a morphological and a metabarcoding approach to analyse the shortterm effects of mechanical dredging for Arenicola spp., a bioturbating lugworm, on the locally present benthic community. Both methods indicated a slow recovery of long-lived species after dredging combined with an increased abundance of opportunistic species in the first spring/summer seasons. In line with previous research (van den Heiligenberg 1987, Leopold \& Bos 2009), the observed impact was hypothesized as due to complete removal of lugworms from the sediments as well as the physical relocation and disturbance of the sediment. The combined use of the 2 methodological approaches per- 
a) Annelida

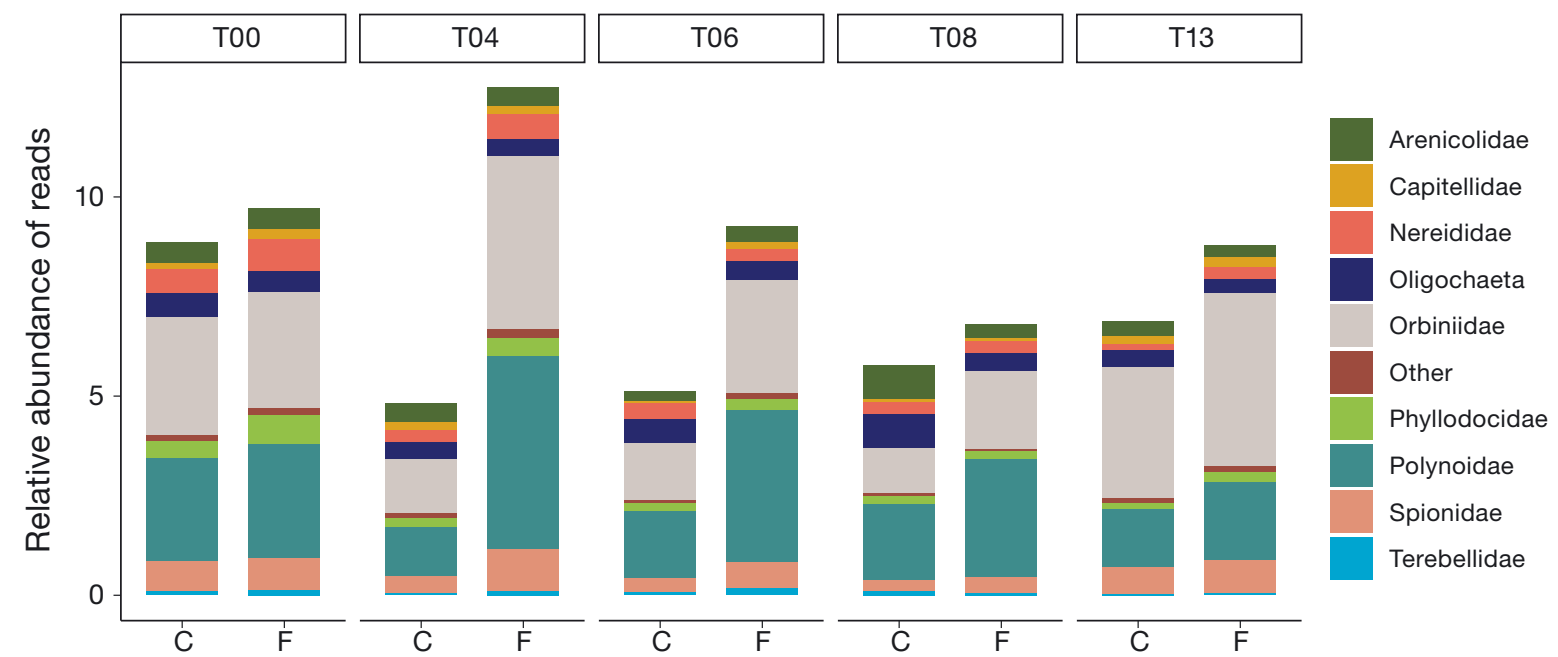

b) Arthropoda
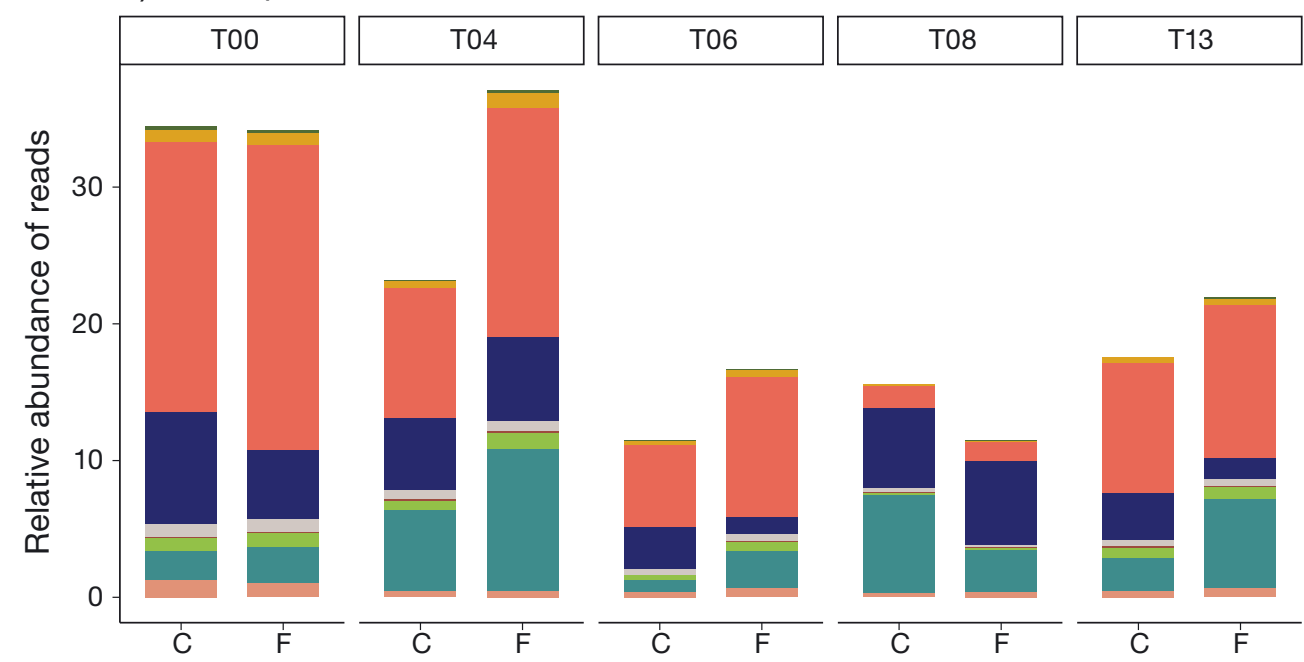

C) Nematoda

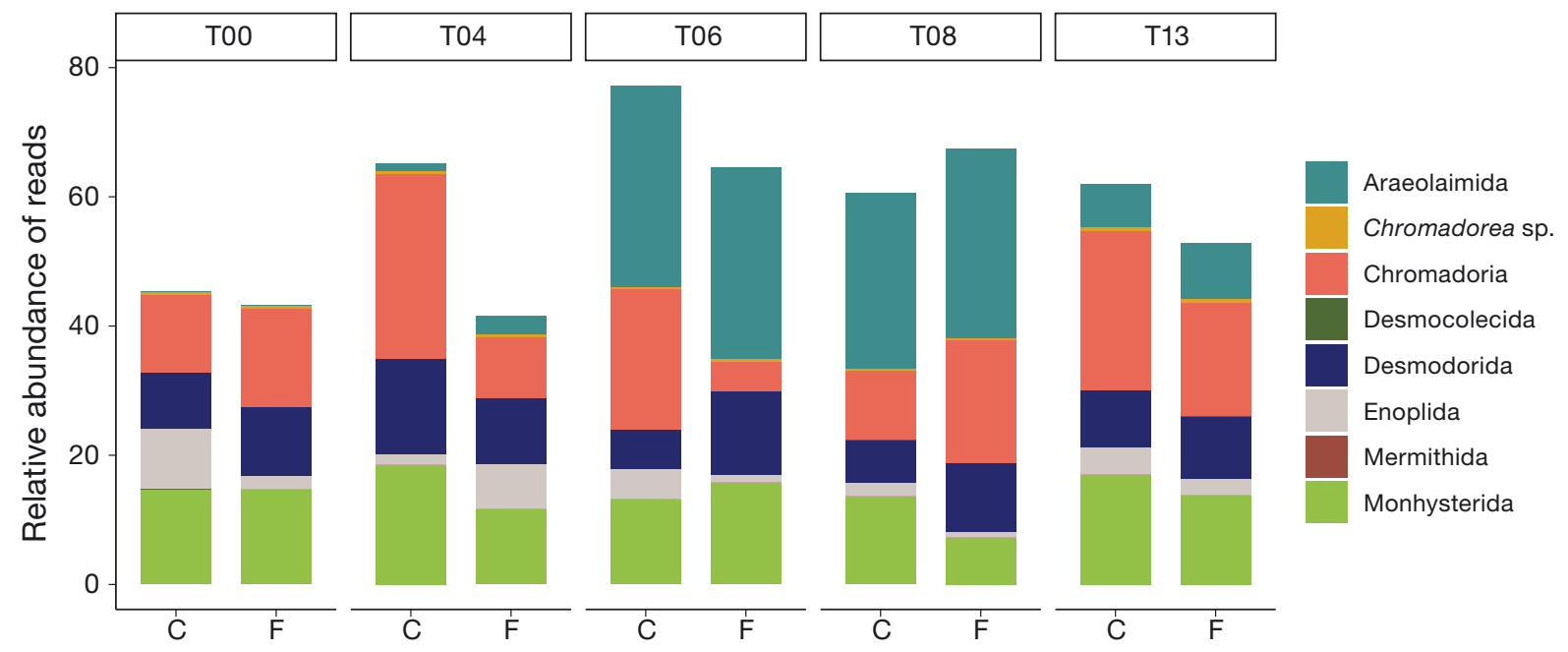

Fig. 6. Molecular analysis of benthic biodiversity: selection of barplots based on relative read abundance for (a) Annelida, (b) Arthropoda and (c) Nematoda families or classes obtained via metabarcoding. Barplots for all sampling events can be found in Figs. S5-S7. C: control; F: fished; TXX: sampling time point 
mits direct comparisons between the methods (Cowart et al. 2015, Lejzerowicz et al. 2015).

\subsection{Effects of mechanical dredging}

Mechanical dredging for Arenicola spp. caused prominent digging tracks within the intertidal mudflats. These tracks remained, although slightly visible, for at least $1.5 \mathrm{yr}$. Unfortunately, we do not have records beyond that period. Grain size patterns were measured as percentage silt for both the tracks as well as the control transects. Silt content was relatively low, with percentages between 2.5 and $6.9 \%$ (Klunder et al. 2019a). Significant differences in grain size patterns were measured between the control and fished samples. The percentage of silt fluctuated more in the fished samples compared to the control samples, especially in the second year; an effect which has also been described after cockle dredging (Piersma et al. 2001). Benthic species are both influenced by and influence (bioturbation) sediment characteristics. The removal of Arenicola spp., a taxon that contributes heavily to sediment bioturbation, might be the cause of the differing grain size patterns measured, including the high porosity long after dredging (Volkenborn et al. 2007).

The most prominent differences in species composition between the fished and control transects were found from April through July, the spring/summer season. MDS ordinations for both the morphological and molecular approaches showed significant differences in community composition in April and May of the first year following dredging, whereas trends in abundances for both approaches also showed differences from April through July in the second year. Life cycles of intertidal marine benthic species in temperate areas, such as the Wadden Sea, are known to follow distinct seasonal patterns, which for most species include hibernation in winter and increased activity in spring/summer due to higher availability of food resources (Beukema 1974, Coma et al. 2000). The largest differences in community composition and species abundances for both years were found within the spring/summer season - the season with increased activity — suggesting recovery rates within the disturbed environment are influenced by the spring/summer activity of the species present (Arntz \& Rumohr 1982).

The taxa studied within this experiment showed different recovery rates; taxa adapted to rapid colonization - opportunistic species - can recover more quickly than long-lived and slow-growing species
(Newell et al. 1998). Within this study, an increased abundance of these opportunistic taxa, such as Pygospio sp. and Capitella sp., was observed within the first spring/summer season with the morphological approach as well as an increased RRA of Spionidae and Capitellidae. These increased abundances shortly after dredging are consistent with predicted capacity for rapid recolonization (Savidge \& Taghon 1988, Shull 1997, Newell et al. 1998). However, the second spring/summer season also showed a higher abundance of these species in the fished tracks compared to the control tracks. This oscillation in species abundances during community succession has been shown before within the first 2 yr after recolonization by Arntz \& Rumohr (1982), who reported that while oscillations were in phase with the seasonal oscillations, this only became normalized in the third year.

Recovery rates for long-lived and slow-growing species, such as Arenicola, were slower compared with other annelid taxa. Both count numbers of adult specimens and the RRA for Arenicolidae were lower in the fished transects until $1.5 \mathrm{yr}$ after dredging at nearly all sampling events. This trend of prolonged suppression of lugworm numbers after dredging was also observed in earlier studies (van den Heiligenberg 1987, Beukema 1995). Moreover, higher recruitment of juvenile specimens was observed in the fished transects (van den Heiligenberg 1987). With the molecular approach, it is not (yet) possible to distinguish between juvenile and adult specimens; the RRA is a rough measure of biomass (Lamb et al. 2019). Adult specimens contribute more to the total biomass than juvenile specimens. Therefore, RRA will be biased based on the relative body size of adults compared to juveniles.

Explanations for differences in recovery rates and colonization mechanisms have been discussed widely, with both passive and active transport mechanisms and recruitment proposed (e.g. Arntz \& Rumohr 1982, Savidge \& Taghon 1988, Shull 1997, Newell et al. 1998). Taxa with larval recruitment (e.g. Capitella sp.) and mobile taxa (e.g. Pygospio sp. and Podocopida) are able to rapidly colonize a disturbed area (Savidge \& Taghon 1988, Shull 1997). Once settled, these taxa grow and reproduce quickly due to the absence of competition with larger bodied, slow-growing taxa (Newell et al. 1998). These opportunistic taxa have versatile reproductive strategies which allows for rapid recolonization. For instance, Pygospio sp. is able to reproduce both sexually and asexually in different seasons (Gudmundsson 1985). 
Field observations and photographs in the present study suggest a high abundance of diatoms within the fished transects during spring. Although diatom layers are observed naturally on the mudflats (Scholz \& Liebezeit 2012), the diatom layers on the dredged gullies were clearly visible, whereas these layers were not visible in the surrounding area and control transects. This high observed abundance is possibly related to higher nutrient availability in the fished transects compared to the control transects, resulting from decaying organisms and/or increased sediment oxidation. This in turn might contribute to increased spring-summer benthic invertebrate abundance in these fished transects (Newell et al. 1998). Especially meiofauna taxa such as Desmodorida and Podocopida demonstrated a rapid increase in RRA directly after dredging; possibly advancing from higher food availability (Boyd et al. 2000).

\subsection{Comparison between methods}

Both approaches demonstrated a significant effect of Arenicola spp. fishing. However, there was a difference regarding the time-range in which this effect was found. The molecular approach detected an effect slightly earlier in the sampling scheme than the morphological approach. The most obvious reason for this difference would be the difference in communities sampled (Elbrecht et al. 2017, Klunder et al. 2019b). The meiofaunal community was included with the molecular approach but was not studied using the morphological approach. The earlier response observed with the molecular approach might be due to an earlier detection of larvae and/or juvenile specimens from macrofauna taxa before the morphological approach was able to detect them, as these larvae or small juveniles would have been washed through the sieve. Another possible explanation could be the more rapid response by true meiofaunal taxa such as Nematoda and small Arthropoda because of their shorter life cycles and reproductive strategies (Boyd et al. 2000, Balsamo et al. 2012, Fonseca et al. 2014). A third possible explanation is the power of the PERMANOVA analysis. A larger number of OTUs was obtained with the molecular approach, reflecting a larger sampling effort, hence more power for the multivariate analysis (Anderson \& Santana-Garcon 2015). The p-values derived from the PERMANOVA analysis for the morphological approach at T03 and T04 (Table 2) were non-significant, but still relatively low, whereas the molecular approach showed a significant effect. Therefore, the difference in these outcomes could be due to a difference in sampling effort (Anderson \& Santana-Garcon 2015)

All taxa detected with the morphological approach were also detected at the family level with the molecular approach. However, relative quantities between the taxa differed. For Annelida, Capitella sp. was the most abundant taxon detected in the first springsummer season in the morphological data; however, RRA of Capitellidae was low compared to other Annelida families. Possible explanations for this are that the RRA is more directly related to biomass than species counts (Lamb et al. 2019), and the amount of DNA found in the sediment is highly influenced by ecological factors, such as seasonality or tidal movements, driving the release and dispersal of DNA (Barnes \& Turner 2016, Stewart 2019). Nevertheless, patterns observed for most taxa are comparable between the 2 methods. For example, a lower abundance of adult Arenicola spp., Capitella sp. or Pygospio sp. in either fished or control transects in the morphological approach is reflected in a lower RRA of, respectively, Arenicolidae, Capitellidae or Spionidae in the same transects in the molecular approach.

\subsection{Concluding remarks}

The impacts of mechanical dredging for Arenicola spp. were found to last at least $1.5 \mathrm{yr}$ after dredging at the fished transects. Small opportunistic taxa were observed to thrive during their known reproductive season in spring-summer within the fished transects, whereas large-bodied, long-lived taxa showed lower abundance after fishing. Both the morphological approach and the molecular approach detected these changes but the power of the latter appeared to be larger.

Acknowledgements. We thank Arenicola B.V. for providing us with an experimental field and Natuurmonumenten for permission to sample. Also, we are grateful to all the staff and students, and in particular Rowan Stavast, who helped collect our field samples, sort them in the benthic lab, and process them in the molecular lab. We thank Simone Miguel for her help in the silt content analysis.

\section{LITERATURE CITED}

Anderson MJ, Santana-Garcon J (2015) Measures of precision for dissimilarity-based multivariate analysis of ecological communities. Ecol Lett 18:66-73

Arntz WE, Rumohr H (1982) An experimental study of macrobenthic colonization and succession, and the importance 
of seasonal variation in temperate latitudes. J Exp Mar Biol Ecol 64:17-45

Aylagas E, Mendibil I, Borja A, Rodriquez-Ezpeleta N (2016) Marine sediment sample pre-processing for macroinvertebrates metabarcoding: mechanical enrichment and homogenization. Front Mar Sci 3:1-8

Balsamo M, Semprucci F, Frontalini F, Coccioni R (2012) Meiofauna as a tool for marine ecosystem biomonitoring. In: Cruzado A (ed) Marine ecosystems. InTechOpen, London, p 77-104

Barnes MA, Turner CR (2016) The ecology of environmental DNA and implications for conservation genetics. Conserv Genet 17:1-17

* Beukema JJ (1974) Seasonal changes in the biomass of the macro-benthos of a tidal flat area in the Dutch Wadden Sea. Neth J Sea Res 8:94-107

* Beukema JJ (1995) Long-term effects of mechanical harvesting of lugworms Arenicola marina on the zoobenthic community of a tidal flat in the Wadden Sea. Neth J Sea Res 33:219-227

Beukema JJ, Cadée GC (1997) Local differences in macrozoobenthic response to enhance food supply caused by mild euthropication in a Wadde Sea area. Food is only locally a limiting factor. Limnol Oceanogr 42:1424-1435

Beukema JJ, Dekker R (2012) Estimating macrozoobenthic species richness along an environmental gradient: sample size matters. Estuar Coast Shelf Sci 111:67-74

Bijkerk R, Dekker PI (1991) De wadpier Arenicola marina (Polychaeta). Ecologisch profiel. Waterstaat, Haren

Boyd SE, Rees HL, Richardson CA (2000) Nematodes as sensitive indicators of change at dredged material disposal sites. Estuar Coast Shelf Sci 51:805-819

Christianen MJA, Middelburg JJ, Holthuijsen SJ, Jouta J and others (2017) Benthic primary producers are key to sustain the Wadden Sea food web: stable carbon isotope analysis at landscape scale. Ecology 98:1498-1512

Coma R, Ribes M, Gili JM, Zabala M (2000) Seasonality in coastal benthic ecosystems. Trends Ecol Evol 15: 448-453

Compton TJ, Holthuijsen S, Koolhaas A, Dekinga A and others (2013) Distinctly variable mudscapes: distribution gradients of intertidal macrofauna across the Dutch Wadden Sea. J Sea Res 82:103-116

Cowart DA, Pinheiro M, Mouchel O, Maguer M and others (2015) Metabarcoding is powerful yet still blind: a comparative analysis of morphological and molecular surveys of seagrass communities. PLOS ONE 10: e0117562

Deagle BE, Thomas AC, McInnes JC, Clarke LJ and others (2019) Counting with DNA in metabarcoding studies: How should we convert sequence reads to dietary data? Mol Ecol 28:391-406

Drent J (2013) Monitoring van effecten op de bodemfauna door wadpierenvisserij op de Vlakte van Kerken in de periode 2008-2011. NIOZ, Texel

Elbrecht V, Peinert B, Leese F (2017) Sorting things out: assessing effects of unequal specimen biomass on DNA metabarcoding. Ecol Evol 7:6918-6926

Fonseca VG, Carvalho GR, Nichols B, Quince C and others (2014) Metagenetic analysis of patterns of distribution and diversity of marine meiobenthic eukaryotes. Glob Ecol Biogeogr 23:1293-1302

Gudmundsson H (1985) Life history patterns of polychaete species in the family Spionidae. J Mar Biol Assoc UK 65: 93-111
Hartmann-Schröder G (1996) Annelida, Borstenwürmer, Polychaeta. $2^{\text {nd }}$ revised edn. Die Tierwelt Deutschlands und der angrenzenden Meeresteile nach ihren Merkmalen und nach ihrer Lebensweise, Vol 58. Gustav Fisher, Jena

Hayward P, Ryland J (eds) (1995) Handbook of the marine fauna of north-west Europe. Oxford University Press, Oxford

Klunder L, Lavaleye M, Kleine Schaars L, Dekker R, Holthuijsen S, van der Veer HW (2019a) Distribution of the dwarf surf clam Mulinia lateralis (Say, 1822) in the Wadden Sea after first introduction. BioInvasions Rec 8: 818-827

Klunder L, Duineveld GCA, Lavaleye MSS, van der Veer HW, Palsbøll PJ, van Bleijswijk JDL (2019b) Diversity of Wadden Sea macrofauna and meiofauna communities highest in DNA from extractions preceded by cell lysis. J Sea Res 152:101764

Lamb PD, Hunter E, Pinnegar JK, Creer S, Davies RG, Taylor MI (2019) How quantitative is metabarcoding: a meta-analytical approach. Mol Ecol 28:420-430

* Lanzén A, Lekang K, Jonassen I, Thompson EM, Troedsson C (2016) High-throughput metabarcoding of eukaryotic diversity for environmental monitoring of offshore oildrilling activities. Mol Ecol 25:4392-4406

Legendre P, Gallagher ED (2001) Ecologically meaningful transformations for ordination of species data. Oecologia 129:271-280

Kejzerowicz F, Esling P, Pillet L, Wilding TA, Black KD, Pawlowski J (2015) High-throughput sequencing and morphology perform equally well for benthic monitoring of marine ecosystems. Sci Rep 5:13932

Leopold MF, Bos OG (2009) Duurzaamheid van de mechanische wadpierenvisserij in de Waddenzee. Rapport C013/09. IMARES, Texel

Levin LA, Boesch DF, Covich A, Dahm C and others (2001) The function of marine critical transition zones and the importance of sediment biodiversity. Ecosystems 4: 430-451

* Luttikhuizen PC, Dekker R (2010) Pseudo-cryptic species Arenicola defodiens and Arenicola marina (Polychaete: Arenicolidae) in Wadden Sea, North Sea and Skagerrak: morphological and molecular variation. J Sea Res 63: $17-23$

*McLusky DS, Anderson FE, Wolfe-Murphy S (1983) Distribution and population recovery of Arenicola marina and other benthic fauna after bait digging. Mar Ecol Prog Ser 11:173-179

McMurdie PJ, Holmes S (2014) Waste not, want not: why rarefying microbiome data is inadmissible. PLOS Comput Biol 10:e1003531

Newell RC, Seiderer LJ, Hitchcock DR (1998) The impact of dredging works in coastal waters: a review of the sensitivity to disturbance and subsequent recovery of biological resources on the sea bed. Oceanogr Mar Biol Annu Rev 36:127-178

* Piersma T, Koolhaas A, Dekinga A, Beukema JJ, Dekker R, Essink K (2001) Long-term indirect effects of mechanical cockle-dredging on intertidal bivalve stocks in the Wadden Sea. J Appl Ecol 38:976-990

* Pruesse E, Quast C, Knittel K, Fuchs BM and others (2007) SILVA: a comprehensive online resource for quality checked and aligned ribosomal RNA sequence data compatible with ARB. Nucleic Acids Res 35: 7188-7196 
R Core Team (2018) R: a language and environment for statistical computing. R Foundation for Statistical Computing, Vienna

Savidge WB, Taghon GL (1988) Passive and active components of colonization following two types of disturbance on intertidal sandflat. J Exp Mar Biol Ecol 115:137-155

Scholz B, Liebezeit G (2012) Microphytobenthic dynamics in a Wadden Sea intertidal flat - Part I: seasonal and spatial variation of diatom communities in relation to macronutrient supply. Eur J Phycol 47:105-119

Shull DH (1997) Mechanisms of infaunal polychaete dispersal and colonization in an intertidal sandflat. J Mar Res 55:153-179

Sinniger F, Pawlowski J, Harii S, Gooday AJ and others (2016) Worldwide analysis of sedimentary DNA reveals major gaps in taxonomic knowledge of deep-sea benthos. Front Mar Sci 3:92

Stewart KA (2019) Understanding the effects of biotic and abiotic factors on sources of aquatic environmental DNA. Biodivers Conserv 28:983-1001

Editorial responsibility: Rochelle D. Seitz, Gloucester Point, Virginia, USA

Reviewed by: W. Ferreira Magalhães and

1 anonymous referee van den Heiligenberg T (1987) Effects of mechanical and manual harvesting of lugworms Arenicola marina L. on the benthic fauna of tidal flats in the Dutch Wadden Sea. Biol Conserv 39:165-177

Volkenborn N, Reise K (2006) Lugworm exclusion experiment: responses by deposit feeding worms to biogenic habitat transformations. J Exp Mar Biol Ecol 330: 169-179

*Volkenborn N, Hedtkamp SIC, van Beusekom JEE, Reise K (2007) Effects of bioturbation and bioirrigation by lugworms (Arenicola marina) on physical and chemical sediment properties and implications for intertidal habitat succession. Estuar Coast Shelf Sci 74:331-343

Wolff WJ, Binsbergen MA (1985) The ecology of the Wadden Sea: Vol 1-3. A.A. Balkema, Rotterdam

* Zeppilli D, Sarrazin J, Leduc D, Arbizu PM and others (2015) Is the meiofauna a good indicator for climate change and anthropogenic impacts? Mar Biodivers 45: 505-535

Submitted: December 23, 2020

Accepted: July 1, 2021

Proofs received from author(s): August 25, 2021 